\title{
Education and Vocational Training in Kosovo, A Challenge and Objective of the 21st Century
}

\author{
Ph.D. Safet Krasniqi \\ University "Ukshin Hoti" in Prizren \\ safet.krasniqi@uni-prizren.com
}

Article History: Received: 10 November 2020; Revised 12 January 2021 Accepted: 27 January

2021; Published online: 5 April 2021

\begin{abstract}
Classes in Kosovo are held in private and public educational institutions. Education in Kosovo went through very hard phases and challenges especially in the years 1990/1999 since differences and the need for change made us not entirely prepared. After the establishment of Kosovo Institutions, the Department of Education and Science (DES) was established within the Ministry of Education. The primary aim was to establish the legal and professional basis as a frontline of the reform of our education system, especially the acceptance of the Bologna processes that facilitate the radical reform of general and vocational education. This paper will address the aspects of reforming and progression of vocational secondary education, vocational schools, and correspondence to the needs of the EU market and the possibility of implementing in post-secondary and university higher education.
\end{abstract}

Keywords: Ministry of Science and Education, KEEN - Kosovo Education for Employment Network, KESP- Kosovo Education Strategic Plan, VET- Vocational and educational training, AGAdministrative Guidance, MDE- Municipal Directorate of Education, HSVT- High school vocational training.

\section{Methodology used}

During my research, I used documents, publications, official documents, reports from international donors and agencies in the field of policy-making. Also, I applied the comparative analytical method and partly the historical method.

\section{Content}

When we talk about improving and professionalizing education in Kosovo, we could say that laws and legal acts in force have been drafted, which regulate the scope of activity of this segment of education. Also, there are several NGOs which through their reports monitored the implementation of laws and other legal acts related to Vocational Education and Training as well as the implementation of these legal documents by the Government of the Republic of Kosovo. Assess 
The Organization, "Kosovo Education for Employment Network - KEEN" from 2019 with the title, Vocational Education and Training in Kosovo; Challenges and opportunities, April 2019 considers that in addition to education, Kosovo also needs to professionalize the workforce, which is the task of the MES. When we say that it is the task of MES then we say that students must acquire the necessary skills to be competitive in the labor market.

Kosovo Education Strategic Plan, 2017-2021 (KESP), is the main document for the development of the education sector in Kosovo that describes the sector of education and vocational training as one of the seven areas of planning. The basis of vocational education and training is the National Qualifications Curriculum. This document was based on the general situation of the population able to work as well as the current situation in Kosovo. According to this document the unemployment rate in 2018 reached $29.4 \%$. The unemployment rate among young people aged 15-24 is even higher, 55\%. The said report refers to World Bank statistics according to which Kosovo's economy should grow by about $6 \%$ per year to reduce the overall unemployment by the first half of the 10 years, assuming an annual increase in labor power share by $1.9 \%$ and productivity employment growth flexibility of 1.6\%. However, as the statistics of the period 2009-2017 show, the domestic gross product increased only $3.5 \%$. The high unemployment rate indicates the loss of human capital which the economy will never be able to recover. The young population is usually considered an asset to a country's economy. They are the future employees who will theoretically contribute to growth ${ }^{1}$.

Young people's interest in Vocational Education and Training has increased in recent years. Statistics for $2017 / 2018$ show that 86,813 students were enrolled in the upper secondary level, of which 46,205 students were registered in vocational education schools compared to 40,608 students registered in gymnasiums or 53\% registered in VET-Schools compared to $47 \%$ registered in secondary schools (gymnasiums). It is estimated that students are enrolled in 17 professional fields and 140 profiles 21 . Divided by gender, the data show that compared to women, men are more likely to enroll in VET schools. Thus, education statistics in 2018 show that 27,389 males were enrolled in VET schools compared to 18,816 females; while the number of male students in gymnasiums is 16,982 compared to 23,626 females 22 . Percentage-wise $58.2 \%$ of women are enrolled in gymnasiums compared to $40.7 \%$ enrolled in vocational schools. Recent changes in student enrollment in vocational education can be attributed to external factors, namely the possibility of migration after visa liberalization to the labor markets in European countries that require a technically skilled workforce. Table $1^{2}$.

Number of students registered in Vocational Education and Training: 2014 - 2018

Table 1.

\begin{tabular}{|l|l|l|l|l|}
\hline Year & $2014 / 15$ & $2015 / 16$ & $2016 / 17$ & \\
\hline
\end{tabular}

\footnotetext{
${ }^{1}$ Vocational Education and Training in Kosovo: Challenges and Opportunities, Published by the project "Kosovo Network for Education and Employment - KEEN", April 2019, Prishtina

${ }^{2}$ Kosovo Agency of Statistics (2018) https://masht.rks-gov.net/uploads/2018/07/statistikat-e-arsimit-ne-kosove-2017-18 consulted on date; 02/03/2020.
} 


\begin{tabular}{|l|l|l|l|l|}
\hline & & & & \\
\hline $\begin{array}{l}\text { Number } \\
\text { of persons } \\
\text { employed }\end{array}$ & 41,940 & 42,600 & 45,462 & 46,205 \\
\hline $\begin{array}{l}\text { Employed } \\
\text { women }\end{array}$ & $2014 / 15$ & $2015 / 16$ & $2016 / 17$ & $2017 / 18$ \\
\hline $\begin{array}{l}\text { Employed } \\
\text { women }\end{array}$ & 16,182 & 16,723 & 18,258 & 18,816 \\
\hline
\end{tabular}

In terms of the level of education according to the needs of the EU market, the greatest difficulties in Kosovo occur in terms of finding employees with the required qualifications, who are needed for different work processes. The study conducted by the American Chamber in 2017, confirms the existence of numerous professional deficiencies particularly in manufacturing, especially in technical directions. This study is part of the project, "Development of the Private Sector through the implementation of the Stabilization and Association Agreement (SAA) " aiming to research and find opportunities for harmonization of the education sector concerning the labor market for the Kosovar companies to compete in the EU market. Based on the information provided by the Kosovo Agency of Statistics for the second quarter of 2018, there is an increase in employment in Kosovo ${ }^{3}$. Table 2.

\begin{tabular}{|l|l|l|l|l|}
\hline & Total & EU & Men & $\begin{array}{l}\text { Women and } \\
\text { girls }\end{array}$ \\
\hline Employed & $341,600 / 28.5 \%$ & $68.6 \%$ & $269,800 / 44.8 \%$ & $71,800 / 12.0 \%$ \\
\hline $\begin{array}{l}\text { Active } \\
\text { workforce }\end{array}$ & $484,200 / 40.4 \%$ & $73.8 \%$ & $380,700 / 63.1 \%$ & $103,500 / 17.4 \%$ \\
\hline $\begin{array}{l}\text { Inactive persons } \\
\text { in the labor } \\
\text { market }\end{array}$ & $714,314 / 59.6 \%$ & $26.2 \%$ & $222,628 / 36.9 \%$ & $491,327 / 82.6 \%$ \\
\hline Unemployment & $142,500 / 29.4 \%$ & $6.8 \%$ & $110,800 / 29.1 \%$ & $31,700 / 30.6 \%$ \\
\hline $\begin{array}{l}\text { Unemployment } \\
\text { from the age } \\
15-24\end{array}$ & $40,400 / 55.0 \%$ & $15.0 \% / 27,500$ & $27,500 / 51.8 \%$ & $13,000 / 63.2 \%$ \\
\hline
\end{tabular}

Based on the information there are 68 vocational schools in the Republic of Kosovo that is under the management of municipalities. Periodically, the number of students enrolled in these schools has changed due to the changing needs of the labor market. The largest number of enrolled students in vocational secondary schools is in technical fields, then in health, social welfare, and administration. These vocational schools offer International Education Standards programs (ISCED). The number of vocational schools in Kosovo that offer ISCED level programs is 68 , and most of them are managed by the relevant municipal authorities. The number of teachers in Vocational Education and Training schools is 3,154, of which

\footnotetext{
${ }^{3}$ American Chamber of Commerce in Kosovo, Education and Labor Market in Kosovo and the European Union, Education and Labor Market in Kosovo and the European Union Project "Private Sector Development through the implementation of the SSA", Pristina, December 2018, p.5.
} 
1,287 are women. 23 Over the years, the number of students enrolled in VET has increased, indicating that more young people are enrolling in VET than in general education schools. Preferred fields of study are engineering, production, and construction, then business, administration, and law, as well as health and social welfare ${ }^{4}$.

Table -3

Percentage of students registered in Vocational Education and Training (VET) institutions

\begin{tabular}{|c|c|c|c|c|}
\hline $\begin{array}{l}\text { ISCED fields } \\
\text { (The } \\
\text { International } \\
\text { Standard } \\
\text { Classification } \\
\text { of Education) }\end{array}$ & $2015 / 2016$ & $2016 / 2017$ & $2017 / 2018$ & $2018 / 2019$ \\
\hline $\begin{array}{l}\text { Arts and human } \\
\text { sciences }\end{array}$ & $2.66 \%$ & $2.91 \%$ & $3.3 \%$ & $3.31 \%$ \\
\hline $\begin{array}{l}\text { Business } \\
\text { administration, } \\
\text { law }\end{array}$ & $31.68 \%$ & $29.86 \%$ & $29.54 \%$ & $28.27 \%$ \\
\hline $\begin{array}{l}\text { Production and } \\
\text { Construction }\end{array}$ & $31.98 \%$ & $33.80 \%$ & $32.69 \%$ & $33.18 \%$ \\
\hline $\begin{array}{l}\text { Agriculture, } \\
\text { Forestry, } \\
\text { Viticulture and } \\
\text { Fishery }\end{array}$ & $3.99 \%$ & $2.87 \%$ & $3.90 \%$ & $3.52 \%$ \\
\hline $\begin{array}{l}\text { Health and } \\
\text { social welfare }\end{array}$ & $15.03 \%$ & $15.76 \%$ & $16.23 \%$ & $18.31 \%$ \\
\hline Services & $2.71 \%$ & $2.77 \%$ & $2.79 \%$ & $2.48 \%$ \\
\hline Other & $0,09 \%$ & $0.00 \%$ & $0.18 \%$ & $0.04 \%$ \\
\hline
\end{tabular}

The report of the European Commission for Kosovo, regarding the economic reforms of Kosovo, 2019-2021, Brussels, 11.4.2019 SWD (2019) and the Report on Kosovo, Brussels, dated 6.10.2020, states that Kosovo has not made any significant progress. The EU, through its programs, funding, and policy coordination of Member States through the open method of coordination, supports education and culture in Kosovo. The VET system lacks practical and applied for courses in most programs. The cooperation of vocational schools and business entities is below the appropriate minimum level. This makes it difficult for donors and private businesses to obtain projects. There is a lack of effort to give children with disabilities the opportunity for quality education. In 2018, 75 new assistants qualify to work with children/students with special needs, adding the first group of 54. About 53 assistants were employed in $2019^{5}$.

\footnotetext{
${ }^{4}$ Vocational Education and Training in Kosovo, ibid , p. 15-16

${ }^{5}$ Progress Report for Kosovo, Brussels, 6.10.2020, p.83
} 
Teachers in VET centers have the necessary formal qualifications but are not equipped with adequate professional development opportunities. Furthermore, there is a lack of teaching materials and textbooks. There is still a discrepancy between labor market needs and education outcomes. MEST as an objective has foreseen the increase of the percentage of registered students. The performance of the labor market lags far behind the region and the EU and especially the disproportion between the increase in the workforce and new jobs. Another issue worth discussing is the participation of women in the labor market. Economic growth has not contributed to employment as the growth of the able-bodied population exceeds the number of new jobs. In 2018, the labor force participation rate declined to $40.9 \%$ from $42.8 \%$ from a year earlier. In terms of gender, the participation of women was only $18.4 \%$, which means that one-third of economically active women are unemployed (33.4\%).

In 2017 , the overall employment rate was $28.8 \%$ compared to $29.8 \%$ in the previous year, while the wide employment gap between the male and female population $(45.3 \%$ and $12.3 \%$, respectively) continued. The unemployment rate fell to $29.6 \%$ in 2018, from $30.5 \%$ in 2017 . Overall, unemployment in Kosovo increased further and reached $55.4 \%$ from $52.7 \%{ }^{6}$ in 2017. The outcome of this is that the workforce is a challenge in itself in terms of gaining basic knowledge to practice a certain vocation. As a concrete example regarding pre-primary education, Prizren can be the second-largest municipality in Kosovo in terms of the number of inhabitants and territory; there are currently 1750 children attending public pre-primary schools. In the public institutions of the Municipality of Prizren, there are 1820 teachers, of which 52 in pre-primary education, 502 in primary education, 1004 in the level of lower secondary education, and 330 are employed in the upper secondary schools of the Municipality $^{7}$. For 2017, the Municipality of Prizren has allocated 16,163,477 euros for expenditures in pre-university education.

Table 4. 2017 pre-university education budget

\begin{tabular}{|l|l|l|l|l|l|l|}
\hline Source & $\begin{array}{l}\text { Salaries } \\
\text { and daily } \\
\text { wages }\end{array}$ & $\begin{array}{l}\text { Goods } \\
\text { and } \\
\text { services }\end{array}$ & $\begin{array}{l}\text { Utility } \\
\text { costs }\end{array}$ & $\begin{array}{l}\text { Subsidies } \\
\text { and } \\
\text { transfers }\end{array}$ & $\begin{array}{l}\text { Capital } \\
\text { expenditures }\end{array}$ & Total \\
\hline $\begin{array}{l}\text { Government } \\
\text { grants }\end{array}$ & $13,088,879$ & $1,044,098$ & 254,000 & - & 810,350 & $15,197,327$ \\
\hline $\begin{array}{l}\text { Own source } \\
\text { revenues }\end{array}$ & 70,000 & 178,500 & - & 85,000 & 632,650 & 966,150 \\
\hline Total & $13,158,879$ & $1,222,598$ & 254,000 & 85,000 & $1,443,000$ & $16,163,477$ \\
\hline
\end{tabular}

Table. 4 shows that $81.4 \%$ of operating expenditures for the education sector of the Municipality of Prizren are dedicated to salaries. Approximately $20 \%$ of the budget is used by the Municipal Directorate of Education for the expansion, improvement, and maintenance of school infrastructure. The rate of public current expenditures per student as a percentage of

\footnotetext{
${ }^{6}$ Ibid, pp. 18-21

${ }^{7}$ Education development plan, 2017-2021 in the municipality of Prizren, Prizren, 2017
} 
Gross Domestic Product per capita is $12.32 \% 10$ which is below the national average of $14.9 \%^{8}$.

This report also includes future objectives related to accountability, increasing the performance of directors and other responsible persons, implementing curricula, quality assurance, etc. The objective of the municipality regarding the professionalization and adaptation of educational profiles in the municipality of Prizren, the labor market, and the needs of the market in the country and markets outside Kosovo is missing. The most challenging are the profiles that need to be opened or strengthen the existing ones that tempt students to enroll. This approach has to do with the empowerment and professionalization of vocational schools which have a long experience in the municipality of Prizren. An example of this is the technical high school in Prizren, which for decades has provided professional staff to the local industry in Prizren and generally to the labor market in Prizren. Various trades have been taught in this school (tanner, silversmith, mechanic, trade, food technician, etc.) which have covered the needs of the labor market in Prizren (the former shoe factory in Prizren, textile factory, food technology factory, commercial enterprises, production of handicrafts, etc.) and these enterprises used to have an internal and external market for the placement of their products ${ }^{9}$.

\section{Challenges}

Among the challenges that negatively affect the continuous professional development of teachers of vocational education and training according to the Report of the Organization "European Training Foundation" titled "Continuous professional development for teachers and trainers of vocational education and training in Kosovo" 2018, are: the dominance of men over the age of 50 in management of the school as more than half of them have no previous experience in school management, monitoring the performance of teachers is performed through direct observation conducted by principals or other management staff of schools, but not by designated mentors.

The lack of teachers with special needs was a critical issue for one-third of vocational schools and the participation of students in vocational practice is a problem in almost half of the schools. Kosovo Education Policies progressed with the development of the Quality Assurance Strategy for Kosovo Pre-University Education 2016-2020, the Strategic Framework for Constant Professional Development Kosovo, the National Development Strategy of Kosovo 2016-2021, KESP 2017-2021, and administrative instructions (AI) enable the implementation of the Teachers Licensing System, Career and Professional Development of Teachers and Educational Employees. This framework aims to make a coherent link between career, standards, and quality development. The licensing process is ongoing. From

\footnotetext{
${ }^{8}$ Annual statistical report with educational indicators 2015/16, MEST, December 2016

${ }^{9}$ The Municipality of Prizren is located in the southwest of the Republic of Kosovo in an area of $640 \mathrm{~km} 2(5.94 \%$ of the territory of Kosovo) and consists of 76 settlements with 220,776 inhabitants3. One of the features of the Municipality of Prizren is its multi-ethnic character, as different communities coexist in it, such as: Albanians, Bosniaks, Turks, Gorani, Roma, Ashkali and Egyptians. Such a characteristic is reflected in all levels of education starting from preschool education to higher education. In the past, the municipality of Prizren had a local industry where different workers with different professions were employed. The industry in the municipality of Prizren was state-owned.
} 
2012 to $2017,96.55 \%$ of teachers have attained career licenses. From the survey results, $47 \%$ of vocational teachers in Kosovo have participated in another type of Constant Professional Development during the previous 12 months $^{10}$.

Teachers' participation in the Conference was the same, but there was an increase from 18\% to $32 \%$ of teachers who had the opportunity to attend and learn from other schools. Business training has increased from $16 \%$ (2015) to $35 \%$ (2018). About $62 \%$ of teachers of professional subjects attended at least 30 classes of Continuous Professional Development (2015: 48\%). This suggests that the duration of Continuous Professional Development (CPD) has increased for those with a face in Continuous Professional Development. Only $42 \%$ of all teachers have more than 2 classes of training of Continuous Professional Development. There has been a small difference in the percentage of teachers who participated in the CPD (37\%) addressing directly their profile or sector $(2015: 36 \%)^{11}$.

\section{Government National Strategy for Vocational Education and Training}

The strategic plan is the basic document for the development of the education sector in Kosovo for the years 2017-2021. The legal framework approved by the Kosovo Parliament has been drafted, inferring Law no. 04 / L-032 on Pre-University Education in the Republic of Kosovo, Law no. 03 / L-068 on education in the municipalities of the Republic of Kosovo, Law no. 04 / L-138 on Vocational Education and Training, etc.

Law no. 04 / L-138 on Vocational Education and Training is a basic law that aims to train young people in accordance with the needs of the market, their professionalization, creating a general and professional culture. These principles are based on the principles of lifelong learning, technical-technological progress, and other economic developments ${ }^{12}$. Within this law, the Agency for Vocational Education and Training and Adult Education (AVETAE) has been established, responsible for the administration and management of Vocational Education and Training institutions. The Agency for Vocational Education and Training and Adult Education (AVETAE), currently has a limited role as it does not cover all schools in the territory of the Republic of Kosovo. It is believed that by drafting the secondary legislation this agency will be given additional authorizations for its field of activity ${ }^{13}$. Within the legal acts and rules, secondary legislation (AI, regulations, etc.) has been drafted regarding the definition of the structure and functioning of the Agency for Vocational Education and Training and Adult Education (AVETAE), medium-term and long-term objectives of this Agency for education and vocational training to be better organized and to achieve the greatest success.

By Administrative Instructions, the above Agency has not been given full competencies and authorizations which make it entirely functional and at the same time, the structure of the

\footnotetext{
${ }^{10}$ Ibid p.6

${ }^{11}$ Ibid p.7

12 Law no. 04 / L-138 on Vocational Education and Training, article 4

${ }^{13}$ Ibid, article 13
} 
Agency is not fully defined in these documents, to clarify the mission of this Agency as efficiently as possible ${ }^{14}$.

An important issue is also the financial position of the Agency for Vocational Education and Training and Adult Education (AVETAE), namely the financial possibility for providing educational services in the field of education by natural or legal persons. The purpose of this Administrative Instruction is financial incentives for all legal entities to provide quality services ${ }^{15}$. Kosovo's budget cannot allocate sufficient funds due to budget constraints and lines. The report of the Organization "Aligning Education for Employment (LLED)" on the current situation in vocational education and training, Policy Analysis and Legal Framework, the definition of the selection process and criteria for harmonizing educational programs with the labor market in Kosovo developed by the EIPP for ALLED2 - (European Institute for Public Policy), analyzed the needs of the labor market in Kosovo by economic sectors. According to this report compiled in 2019, the sectors are agriculture, food processing, production, and processing, as well as energy and power supply. In the targeted sector of the ALLED2 project for the sector involved "Production and processing - Mechatronics" there are 17 active schools throughout Kosovo ${ }^{16}$. List of active Vocational Education and Training Schools in the targeted sector of the ALLED 2 project "Production and processing Mechatronics"

Table -5

\begin{tabular}{|l|l|l|}
\hline Municipality & School & Sector Profile \\
\hline Deçan & Tafil Kasumaj & Mechatronics \\
\hline Gjakovë & Nexhmedi Nixha & Production operator \\
\hline Gllogoc & Fehmi Lladrovci & Mechatronics \\
\hline Gjilan & Mehmet Isai & Mechatronics \\
\hline Istog & Mithat Frashëri & Production operator \\
\hline Klinë & Fehmi Agani & Production operator \\
\hline Mitrovica & Arkitekt Sinani & Production operator \\
\hline Lipjan & $\begin{array}{l}\text { Mixed Secondary High } \\
\text { Schools }\end{array}$ & Machinery mechanics \\
\hline Rahovec & Selajdin Mullaabazi & Machinery Mechanics \\
\hline Prishtinë & Prishtinë & CNC \\
\hline Prizren & 11 Marsi & Metal processing \\
\hline Shtime & Sh.M. Profesionale & Machinery mechanics \\
\hline Suharekë & Skender Luarasi & $\begin{array}{l}\text { Production operator } \\
\text { Machinery mechanics }\end{array}$ \\
\hline Ferizaj & $\begin{array}{l}\text { Mechatronics } \\
\text { Production Operator }\end{array}$ \\
\hline
\end{tabular}

\footnotetext{
${ }^{14}$ Administrative Instruction no. 14/2014 Agency for Vocational Education and Training and Adult Education (AVETAE), articles $3,4,5$, and 8

${ }^{15}$ Administrative Instruction no. 21/2016 on the allocation of budget funds from the category of subsidies and transfers

${ }^{16}$ Report of the Organization., Aligning Education for Employment, (LLED) on the study of the current situation in Vocational Education and Training, Policy analysis and legal framework, definition of the selection process and criteria to harmonize educational programs with the market in Kosovo developed by Developed by EIPP for ALLED2 - European Institute for Public Policy, Prishtina, November, 2019, p. 41-42
} 


\begin{tabular}{|l|l|l|}
\hline Viti & Jonuz Zejnullahu & Production operator \\
\hline Vushtrri & Lutfi Musiqi & $\begin{array}{l}\text { Mechatronics } \\
\text { Production Operator }\end{array}$ \\
\hline
\end{tabular}

List of active Vocational Education and Training schools in the targeted sector of the ALLED 2 project, food processing.

Table 6.

\begin{tabular}{|l|l|l|}
\hline Municipality & School & Sector profile \\
\hline Gjakovë & Kadri Kusari & Food processing \\
\hline Gllogoc & Fehmi Lladrovci & Food processing \\
\hline Gjilan & Arbëria & Food processing \\
\hline Klinë & Fehmi Agani & Food processing \\
\hline Mitrovica & Arkitekt Sinani & Food processing \\
\hline Rahovec & Selajdin Mullaabazi & Food processing \\
\hline Pejë & Ali Hadri & Food processing \\
\hline Podujevë & Isa Boletini & Food processing \\
\hline Prishtinë & Abdyl Frasheri & Food processing \\
\hline Prizren & Ymer Prizreni & Food processing \\
\hline Prizren & Anton Ceta & Food processing \\
\hline Suharekë & Skender Luarasi & Food processing \\
\hline Ferizaj & Zenel Hajdini & Food processing \\
\hline Viti & Jonuz Zejnullahu & Food processing \\
\hline Vushtrri & Bahri Haxha & Food processing \\
\hline
\end{tabular}

Fourteen Vocational Education Training schools in 14 municipalities that are active in the targeted sector of the ALLED2 project including "Agriculture" are schools that have been part of the project in order to achieve desired results. In Gjakova, VET School "Kadri Kusari", horticulture, veterinary profile, in Gllogoc VET School "Fehmi Lladrovci" Horticulture, in Gjilan the school "Arberia", Horticulture, Veterinary, and Agribusiness, in Klina, VET School "Fehmi Agani", Horticulture, in Rahovec, VET School "Selajdin Mullaaba", Horticulture, in Peja, VET School "Ali Hadri", Horticulture and Veterinary, in Podujevë, VET School "Isa Boletini" Agribusiness, in Prishtina, VET School "Abdyl Frasheri", Horticulture, Veterinary, and Agribusiness, in Prizren, VET School "Anton Ceta", Agribusiness, in Shtime, VET School, Agribusiness, in Suhareka, VET School "Abdyl Ramaj", Agribusiness and Horticulture, in Ferizaj, VET School "Zenel Hajdini", Horticulture, Veterinary, and Agribusiness, in Viti, VET School Jonuz Zejnullahu Horticulture, in Vushtrri VET School "Bahri Haxha". Veterinary and AGrobusiness ${ }^{17}$.

17 ibid. pg. $42-45$ 


\section{Vocational Education and Training System}

The VET system in Kosovo comprises formal and informal education. Formal education the school, vocational education, and training are organized in grades 10, 11, and 12. Classes and qualifications are developed in modular contents in accordance with the Kosovo Curriculum Framework and Law no. 03 / L-060 on National Qualifications for Vocational Education. The VET system is organized in two levels of Vocational Education and Training; the first level of vocational education is two years, grades 10 and 11. This level enables students to be equipped with a certificate of professional training of craftsmen. Level 3 of the National Qualifications Framework enables the transition to the second level of vocational education, i.e. progression to grade 12 , which enables students to obtain a certificate of qualification of the level of a qualified worker. Level 4 of the National Qualifications Framework enables progression to the third level of vocational education (technicalmanagerial level) or one-year courses that enable progression to post-secondary studies in higher university education ${ }^{18}$. In Kosovo, there are 122 Vocational Education and Training (VET) profiles offered in 67 public VET schools. Among these schools, some schools offer gymnasiums and Vocational Education and Training in 27 municipalities. During the 2018/19 school year, there were 42,986 students, or about $53 \%$ of the total number of high school students ${ }^{19}$.

The Ministry of Labor and Social Welfare through the Employment Agency of the Republic of Kosovo has established eight (8) Vocational Training Centers (VTC) which are located in the seven Regions of the Republic of Kosovo: Prishtina, Prizren, Peja, Gjakova, Ferizaj, Gjilan, Mitrovica and Doljane (northern part of Mitrovica) with 69 workshops and 30 different professions where the training and retraining of persons who are registered as jobseekers, the unemployed and those receiving career guidance services are performed. They are located near all Employment Offices in the municipalities and include (i) Institutional Training in Vocational Training Centers and (ii) Combined Training (Vocational Training Centers and Enterprises). Training is oriented toward improving and adapting professional knowledge, skills, and attitudes necessary for efficient performance within a profession aimed at enhancing the perspective of participants in hiring or retaining employment ${ }^{20}$.

The Ministry of Labor and Social Welfare, in cooperation with the NGO, "ALLED", drafted the project "Harmonization of Education and Training with the Needs of the Labor Market" which is funded by the European Union and the Austrian Development Cooperation (ADC) ) and implemented by the Austrian Development Agency (ADA). This project aims initially to

\footnotetext{
${ }^{18}$ Report reference of KKKs of Kosovo at KEK, AKK, Prishtina, 2016

19 Ibid

${ }^{20}$ The Employment Agency of the Republic of Kosovo, the administration of the Vocational Training Center (QAP) are located in the regions of the Republic of Kosovo: Prishtina, Prizren, Peja, Gjakova, Ferizaj, Gjilan, Mitrovica and Doljane (northern part of Mitrovica)) with 69 workers and 30 different professions. In this center training and retraining of persons who are registered as jobseekers, unemployed and those who receive career guidance services are performed, in addition to all Employment offices in municipalities.
} 
train registered jobseekers and then establish a policy of education based on the labor market, empowerment, and establishment of vocational schools ${ }^{21}$.

\section{Conclusion}

Vocational education and training in Kosovo continue to be a very important link to education in Kosovo. Law enforcement vacuum, low enrollment of students in vocational secondary schools, lack of experts in certain vocational fields, limited budget are obstacles to the functioning of state mechanisms. Kosovo's growing human capital is Kosovo's main source of economic growth. One of the many opportunities for improving the social wellbeing of the people of Kosovo is investing in the vocational education and training sector.

VET is the best way for a school-work transformation. Despite the continuation of education reform in Kosovo, curriculum revisions, communication and cooperation with the private business, teachers' training, however, the VET system continues to have shortcomings which are obstacles to the employment of students attending vocational schools. These shortcomings, in addition to the relationship with private business, the lack of clear curricula that professionalize the student, are also the quality of teaching, lack of teaching and learning materials, incomplete access to professional practice and practical training in schools, etc.

This reality shows that VET should not undergo a drastic restructuring, as one of the main ways through which constant gaps can be filled and economic growth can be sought among the social and economic opportunities for development. Therefore,

\section{Recommendations}

VET in Kosovo, despite making some steps forward, needs further improvement. However, continuous progress is related to efficient cooperation with the relevant institution of Kosovo. Given the need for the professional development of VET aiming to improve the professional experience in school in order to compete in the labor market, the following steps should be made:

- The government, together with the respective parties and stakeholders should work sufficiently in including the private sector equally in VET. This can be achieved by different projects that include private companies specialized in developing professional profiles;

-Allocation of more budget funds is a basic condition that can be used for creating a fund for VET;

-Development of professional profiles based on survey and detailed research regarding the needs of the labor market to remove existing capacity gaps in the labor market;

- Entrepreneurship and school management competencies in VET are a significant condition to provide efficient management, that would lead to providing the best quality teaching and practical capacity building.

${ }^{21}$ Ministry of Labor and Social Welfare, Presentation of the "ALLED II" project. 14.12.2020. 
- Development of career centers in VET institutions to offer support services for students, starting from the career guidance lessons in the classrooms, that would improve their skills; and improving the reputation of the VET sector through effective promotion of the sector with the assistance of political interest parties as well as the private sector.

Improvements in the VET system would lead to more efficient use of human resources, and as a result of this that employees would benefit through employment opportunities and the economy in general by productivity growth.

\section{Literature}

1. Vocational Education and Training in Kosovo: Challenges and Opportunities, published by the project "Kosovo Network for Education and Employment - KEEN", April 2019, Prishtina

2 Kosovo Agency of Statistics (2018) https://masht.rksgov.net/uploads/2018/07/statistikat-e-arsimit-ne-kosove-2017-18 consulted on the date; 02/03/2020.

3 American Chamber of Commerce in Kosovo, Education and Labor Market in Kosovo and the European Union, Education and Labor Market in Kosovo and the European Union Project "Private Sector Development through the implementation of the SAA", Pristina, December 2018, p.5.

4 Vocational Education and Training in Kosovo, ibid., P. 15-16

5 Progress Report for Kosovo, Brussels, 6.10.2020, p.83

6 The education development plan, 2017-2021 in the municipality of Prizren, Prizren, 2017

7 Annual statistical report with educational indicators 2015/16, MEST, December 2016

8 The Municipality of Prizren is located in the southwest of the Republic of Kosovo in an area of $640 \mathrm{~km} 2$ (5.94\% of the territory of Kosovo) and consists of 76 settlements with 220,776 inhabitants3. One of the features of the Municipality of Prizren is its multi-ethnic character, as different communities coexist in it, such as Albanians, Bosniaks, Turks, Gorani, Roma, Ashkali, and Egyptians. Such a characteristic is reflected in all levels of education starting from preschool education to higher education. In the past, the municipality of Prizren had a local industry where different workers with different professions were employed. The industry in the municipality of Prizren was state-owned.

9 Law no. 04 / L-138 on Vocational Education and Training, article 4

10 Administrative Instruction no. 14/2014 Agency for Vocational Education and Training and Adult Education (AVETAE), articles 3,4,5, and 8

11 Administrative Instruction no. 21/2016 on the allocation of budget funds from the category of subsidies and transfers

12 report of the Organization., Aligning Education for Employment, (LLED) on the study of the current situation in Vocational Education and Training, Policy analysis and legal framework, definition of the selection process and criteria to harmonize educational programs with the market in Kosovo developed by EIPP for ALLED2 European Institute for Public Policy, Prishtina, November, 2019p.41-42

13 Report reference of KKKs of Kosovo at KEK, AKK, Prishtinë 2016

14 The Employment Agency of the Republic of Kosovo, the administration of the Vocational Training Center (QAP) are those that are concentrated in the region of the Republic of Kosovo: Prishtina, Prizren, Peja, Gjakova, Ferizaj, Gjilan, Mitrovica and 
Doljane (northern part of Mitrovica)) with 69 workers and 30 different professions. In this center is done skills and re-skills of persons who are registered as job seekers, unemployed, and those who receive career guidance services, in addition to all Employment offices in municipalities.

15 Ministry of Labor and Social Welfare, Presentation of the "ALLED II" project. 14.12.2020. 